\title{
IDENTIFIKASI KOMUNITAS DIATOM YANG BERASOSIASI PADA MAKROALGA Padina sp. DI PERAIRAN PULAU PRAMUKA DAN SEMAK DAUN MELALUI PENDEKATAN METAGENOMIK
}

\author{
Ardian Cahyo Pambudia, Eri Bachtiara, Yuniarti MS ${ }^{a}$, Fiddy Semba Prasetiya ${ }^{a}$ * \\ aUniversitas Padjadjaran, J1. Raya Bandung-Sumedang KM 21 Jatinangor, Sumedang, \\ Jawa Barat 45363, Indonesia
}

*Koresponden penulis : fiddy.semba.prasetiya@unpad.ac.id

\begin{abstract}
Abstrak
Analisis diversitas diatom yang berasosiasi dengan makroalga dapat dimanfaatkan sebagai bahan referensi dalam kegiatan pengelolaan dan konservasi wilayah pesisir. Data yang dihasilkan juga berguna untuk membaca kualitas lingkungan dan bioprospeksi. Penelitian ini bertujuan untuk melihat diversitas komunitas diatom yang berasosiasi dengan Padina sp di Pulau Pramuka dan Semak Daun. Kedua pulau memiliki karakteristik yang berbeda, Pulau Pramuka yang berpenghuni dan terdapat berbagai macam aktivitas masyarakat, sedangkan Pulau Semak Daun tidak berpenghuni. Penelitian ini dilaksanakan pada September 2019 - Mei 2020 di Laboratorium Mikrobiologi dan Bioteknologi Molekuler, Fakultas Perikanan dan Ilmu Kelautan, Universitas Padjadjaran. Proses Next Generation Sequencing (NGS) dilakukan oleh Novogene Co., Ltd di Singapura menggunakan primer Rbcl 646F - 998R dengan target amplicon $331 \mathrm{bp}$. Hasil penelitian didapatkan kelimpahan tertinggi pada ordo Bacillariales di semua stasiun (41-49\%), disusul dengan ordo Fragilariales dan Naviculales.Nilai OTUs tertinggi terdapat pada stasiun 4 (508), disusul dengan stasiun 3 (500), 1 (481), dan 2 (471). Indeks Shannon dan Simpson berada di kisaran $>5$ dan $0<\mathrm{D}<0.5$, yang berarti di semua stasiun memiliki keanekaragaman yang tinggi dan memiliki dominansi yang rendah.
\end{abstract}

Kata kunci: diatom, diversitas, NGS, Padina sp

\begin{abstract}
Diatom diversity analysis associated with macroalgae can be used as a reference material in the management and conservation of coastal areas. The data generated is also useful for reading environmental quality and bioprospection. This study aims to look at the diversity of diatom communities associated with Padina sp on Pramuka Island and Semak Daun. The two islands have different characteristics, Pramuka Island is inhabited and there are various kinds of community activities, while Semak Daun Island is uninhabited. This research was conducted in September 2019 - May 2020 in the Laboratory of Microbiology and Molecular Biotechnology, Faculty of Fisheries and Marine Sciences, Universitas Padjadjaran. The Next Generation Sequencing (NGS) process is carried out by Novogene Co., Ltd in Singapore, using Rbcl primer 646F - 998R with amplicon target $331 \mathrm{bp}$. The results showed the highest abundance in the Bacillariales order at all stations $(41-49 \%)$, followed by the order Fragilariales and Naviculales. The Shannon and Simpson indexes are in the range $>5$ and $0<\mathrm{D}<0.5$, which means that all stations have high diversity and have low dominance.
\end{abstract}

Keywords: diatom, diversity, NGS, Padina sp

\section{PENDAHULUAN}

Mikroorganisme laut hidup bebas di dalam kolom perairan maupun melekat pada permukaan biotik maupun abiotik. Bahkan dalam $1 \mathrm{~mL}$ air laut mengandung lebih dari jutaan virus dan bakteri, ribuan jamur dan mikroalga, dan ratusan larva mikroskopis [1]. Banyak dari mikroorganisme laut tersebut memiliki potensi biofouling atau berinteraksi dengan makro organisme laut secara mutualisme ataupun parasitisme [2].

Permukaan makroalga menyediakan tempat tinggal yang cocok bagi mikroorganisme karena pada makroalga tersebut dapat menyekresikan berbagai macam substansi organik unik seperti extracellular polymeric substances (EPSs) [3] yang 
berfungsi sebagai nutrisi untuk komunitas mikroorganisme yang membentuk biofilm mikroba [4]-[6].

Komunitas mikroorganisme yang bersimbion pada permukaan makroalga hidup membentuk struktur kompleks, dinamik, dan terdiri dari konsorsium mikroorganisme termasuk bakteri, fungi, diatom, protozoa, hingga larva [7]-[10]. Salah satu mikroorganisme yang banyak dijumpai dalam perairan dan bersifat epibiont yaitu diatom.

Diatom biasanya hidup bebas dan melayang - layang di perairan, baik air tawar maupun air laut dan dapat berasosiasi dengan organisme lainnya menjadi simbion pada makroalga [11]. Salah satunya berasosiasi dengan makroalga coklat seperti Padina sp. Belum banyak penelitian terkait eksplorasi dan potensi yang dihasilkan dari mikroorganisme yang bersimbion pada makroalga ini. Namun terdapat beberapa penelitian seperti ditemukannya diatom Haslea nusantara di Pulau Semak Daun [12] yang pigmennya memiliki potensi sebagai antioksidan [13], antibakteri dan antiviral [14], dan efek alelopati terhadap diatom lainnya [15], [16].

Adanya hubungan antara diatom yang menempel pada makroalga ini mempunyai peranan yang penting dalam produsen primer bagi suatu ekosistem perairan. Akan tetapi apabila keberadaan makroalga ini terganggu oleh gangguan fisik, kimia, maupun biologis, maka secara tidak langsung juga akan mempengaruhi keberadaan dari biota perairan lainnya, khususnya diatom.

Tujuan penelitian ini adalah untuk mengetahui keanekaragaman komunitas diatom yang terkait dengan makroalga Padina sp di perairan Pulau Pramuka dan Semak Daun melalui pendekatan metagenomik.

\section{METODE}

Penelitian ini dilakukan pada bulan September 2019 - Mei 2020. Pengambilan sampel makroalga dilakukan pada bulan September 2019 di perairan Pulau Pramuka dan Semak Daun, Kepulauan Seribu. Proses isolasi metagenom diatom dilakukan di Laboratorium Mikrobiologi dan Bioteknologi Molekuler, Fakultas Perikanan dan Ilmu Kelautan, Universitas Padjadjaran. Proses pengurutan amplikon NGS dilakukan oleh Novogene Co., Ltd di Singapura.

\section{Pengambilan sampel makroalga Padina sp}

Sampel makroalga Padina sp diambil di perairan pulau Pramuka dan Semak Daun. Sampel diperoleh pada kedalaman kurang lebih 1 meter, kemudian permukaan thallus disikat menggunakan sikat, kemudian disiram menggunakan air laut kurang lebih $100 \mathrm{~L}$ pada perairan tersebut serta disaring dengan jaring plankton yang ujungnya telah diikat dengan botol sampel berukuran $50 \mathrm{~mL}$, kemudian botol sampel dimasukkan ke dalam coolbox. Pengukuran kualitas air dilakukan secara insitu, sedangkan parameter yang diamati adalah suhu air, oksigen terlarut, $\mathrm{pH}$, dan salinitas yang digunakan sebagai data pendukung kondisi perairan.

\section{Isolasi Metagenom DNA Diatom pada Makroalga}

Sampel yang telah disiapkan kemudian disentrifugasi pada botol sampel berukuran 15 $\mathrm{mL}$ dengan kecepatan $6000 \mathrm{rpm}$ selama 30 menit. Jika sudah, supernatan diambil dan dipindahkan ke botol sampel lain, kemudian botol sampel $15 \mathrm{~mL}$ yang telah diisi sebelumnya diisi ulang dengan sampel supernatan tersebut di botol sampel $50 \mathrm{~mL}$ dengan kecepatan dan waktu yang sama. Supernatan hasil sentrifugasi dipindahkan kembali dan pelet dibiarkan mengendap di dalam tabung. Pellet yang disentrifugasi kemudian digunakan untuk ekstraksi DNA genom menggunakan protokol ZymoBIOMICS ${ }^{\mathrm{TM}}$ DNA Miniprep Kit.

\section{Identifikasi Molekuler Diatom}

Ekstraksi DNA genom diatom menggunakan protokol ZymoBIOMICS ${ }^{\mathrm{TM}}$ DNA Miniprep Kit. Kit ini biasa dipakai oleh peneliti untuk mengisolasi DNA mikroorganisme dari berbagai sampel [17]. Setelah DNA bakteri diperoleh, tahap selanjutnya adalah amplifikasi PCR. Primer yang digunakan untuk PCR adalah gen rbcL menurut Kelly et al. [18], yang merupakan primer rbcL 646F dan 998R. Program PCR yang digunakan adalah: tahap denaturasi awal 
$\left(96{ }^{\circ} \mathrm{C}\right.$ selama 5 menit), denaturasi $\left(96{ }^{\circ} \mathrm{C}\right.$ selama 1 menit), annealing $\left(52{ }^{\circ} \mathrm{C}\right.$ selama 5 menit), elongasi $\left(72{ }^{\circ} \mathrm{C}\right.$ selama 5 menit), setelah mengalami 40 siklus PCR, kemudian dilanjutkan dengan tahap pemanjangan akhir pada suhu $72{ }^{\circ} \mathrm{C}$ selama 5 menit [19]. dan $\operatorname{HOLD}\left(4{ }^{\circ} \mathrm{C}\right.$ selama 7 menit).

Campuran produk PCR termasuk GoTaq ${ }^{\circledR G r e e n ~ M a s t e r ~ M i x ~ P r o m e g a ~(12,5 ~}$ $\mu \mathrm{L})$, rbcL $646 \mathrm{~F}$ primer $(1,25 \mu \mathrm{L})$, rbcL $998 \mathrm{R}$ primer $(1,25 \mu \mathrm{L})$, Nuclease free water $(8 \mu \mathrm{L})$, dan DNA template $(2 \mu \mathrm{L})$ sehingga total produk PCR adalah $25 \mu \mathrm{L} .1 \mathrm{~Kb}$ DNA Ladder (KAPA) sebagai penanda ukuran DNA dan pewarna DNA Loading sebagai DNA ballast. Gel Stain Gel Red sebanyak $10 \mu \mathrm{L}$ dalam 100 $\mathrm{mL}$ TAE 1X untuk gel agarose $0.8 \%$. Kemudian dilakukan elektroforesis untuk mengetahui keberadaan pita DNA genom selama 45 menit dengan arus 80 volt. Selanjutnya proses sequencing amplicon NGS dilakukan oleh Novogene Co., Ltd di Singapura.

\section{Analisis Data}

Data hasil sekuensing NGS kemudian diolah menggunakan software Mothur, Mega $\mathrm{X}$, dan BioEdit untuk mendapatkan hasil berupa data profil keragaman genus diatom. Data yang diperoleh akan diinterpretasikan dan dianalisis secara deskriptif.

Dalam proses pengolahan data bioinformatic, digunakan software Mothur [20] yang sekarang dapat dilakukan dengan platform otomatis yang dikembangkan oleh komunitas "Galaxy Project" [21], [22]. Proses melakukan analisis bioinfromatic dilakukan mengikuti protokol yang disediakan oleh "Team Galaxy Network" [22].

\section{HASIL DAN PEMBAHASAN}

\section{Kualitas Lokasi Pengambilan Sampel Air}

Kondisi perairan pada saat pengambilan sampel terlihat memiliki substrat yang bervariasi mulai dari yang berpasir hingga yang agak kerikil dengan tingkat kekeruhan yang lebih tinggi di Pulau Pramuka dibandingkan di Pulau Semak Daun, sehingga perairan Pulau Semak Daun relatif tenang dan tidak terlalu keruh. Saat pengambilan sampel diatom yang terkait dengan Padina sp. Makroalga, pengukuran kualitas air langsung dilakukan. Parameter yang diukur adalah suhu, oksigen terlarut (DO), salinitas, serta Potensi Hidrogen $(\mathrm{pH})$. Data tersebut dapat dilihat pada tabel berikut (Tabel 1).

Tabel 1. Parameter Kualitas Air Pulau Pramuka dan Pulau Semak Daun

\begin{tabular}{llccccc}
\hline \multirow{2}{*}{ No } & \multirow{2}{*}{ Parameter } & \multicolumn{4}{c}{ Nilai } & \multirow{2}{*}{\begin{tabular}{c} 
Kualitas \\
\cline { 3 - 6 }
\end{tabular}} \\
\cline { 3 - 6 } & & $\mathbf{1 a}$ & $\mathbf{2 a}$ & $\mathbf{3 b}$ & $\mathbf{4 b}$ & \\
\hline 1 & Suhu $\left({ }^{\circ} \mathrm{C}\right)$ & 30,3 & 28,8 & 29,1 & 30,5 & $28-32$ \\
2 & Salinitas $(\%)$ & 25 & 31 & 31 & 30 & $32-34$ \\
3 & $\mathrm{pH}$ & 7 & 7 & 7 & 8 & $7-8,5$ \\
4 & DO $\left(\mathrm{mg} \mathrm{L}^{-1}\right)$ & 4 & 4 & 4 & 4 & $>5$ \\
\hline
\end{tabular}

${ }^{\mathrm{a}}$ Kementerian Lingkungan Hidup, 2004

Sekilas, kualitas perairan di Kepulauan Pramuka dan Semak Daun tidak sesuai dengan baku mutu lingkungan yang dikeluarkan Kementerian Lingkungan Hidup, namun juga tidak terlalu buruk. Dari 4 parameter yang diamati, hanya suhu dan $\mathrm{pH}$ yang termasuk dalam baku mutu.

\section{Hasil Isolasi DNA Genom Diatom}

Sampel yang disimpan dalam tabung 50 $\mathrm{mL}$ disentrifugasi terlebih dahulu agar diatom pada kolom tabung dapat diendapkan membentuk pellet. Selanjutnya ekstraksi DNA dilakukan dengan menggunakan ZymoBIOMICS $^{\mathrm{TM}}$ DNA Miniprep Kit (D4300, Zymo Research).

Hasil visualisasi DNA genom diatom yang disajikan pada Gambar 1 menunjukkan bahwa pita DNA dari genom diatom berada di atas 10.000 bp. Ini karena ukuran genom lebih besar dari 10.000 pasangan basa (bp). Seperti yang diungkapkan oleh Vardi et al. (2008), molekul DNA diatom memiliki ukuran besar yang mengandung kurang lebih 30 megabasa dengan 10.000-12.000 gen yang diprediksi. 


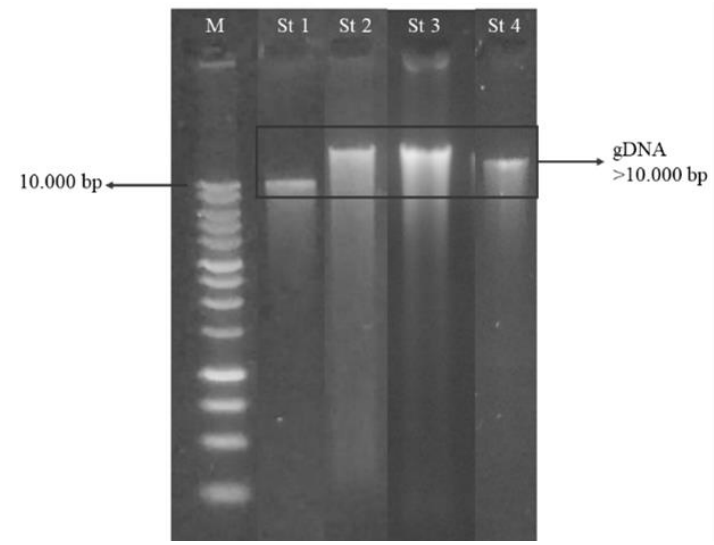

Gambar 1. Visualisasi DNA Genom Hasil Padina sp berasosiasi - diatom dalam Gel Agarose 0,8\%, Tangga DNA M: 1Kb (KAPATM), St1: Station 1, St2: Station 2, St3: Station 3, St4: Station 4.

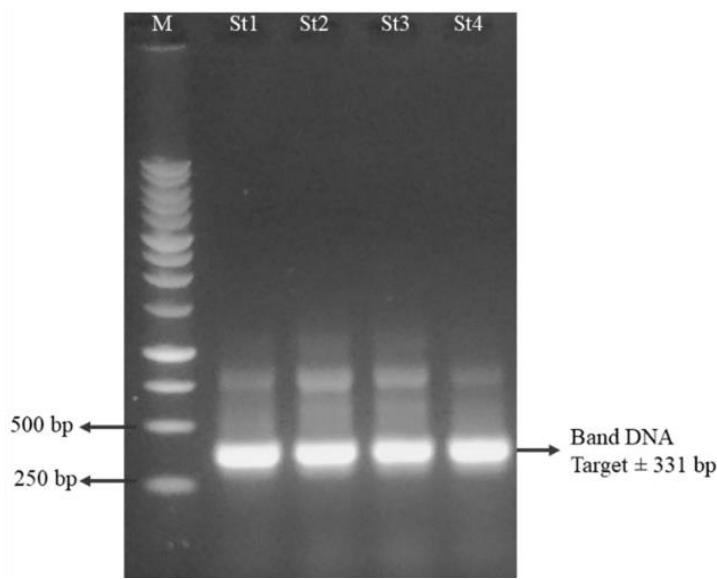

Gambar 2. Hasil Amplifikasi Gen dengan primer rbcL 646F dan rbcL 998R dalam gel agarosa 0,8\%, Tangga DNA M: $1 \mathrm{~Kb}\left(\mathrm{KAPA}^{\mathrm{TM}}\right)$, St1: Stasiun 1,

St2: Stasiun 2, St3: Stasiun 3, St4: Stasiun 4.

Adanya visualisasi pita DNA yang tebal dan tipis dapat disebabkan oleh faktor-faktor tertentu. Pita DNA yang tebal menunjukkan konsentrasi yang tinggi dan DNA total yang terekstraksi secara utuh, sedangkan pita DNA yang tipis dapat disebabkan oleh pergerakan fisik yang berlebihan pada saat pipet, saat membalik larutan dan lain-lain.

Berdasarkan Gambar 2 di atas, dapat disimpulkan bahwa proses amplifikasi gen rbcL diatom berasosiasi Padina sp menggunakan PCR berjalan dengan baik. Hal ini dibuktikan dengan hasil visualisasi dimana PCR ditandai dengan pita DNA yang tebal, serta ukuran pita sampel DNA tersebut sesuai dengan ukuran target produk yaitu $\pm 331 \mathrm{bp}$. Hal ini terlihat dari posisi pita DNA yang dihasilkan berada pada kisaran 250 bp - 500 bp.

Selain itu ada juga noda. Hal tersebut dapat disebabkan oleh penggunaan $\mathrm{Mg}^{+}$, dNTPs, Taq polimerase, primer dan templat DNA yang berlebihan atau adanya kontaminan dalam templat DNA itu sendiri yang menghambat aktivitas taq polimerase; suhu anil dan primer yang tidak sesuai juga dapat menyebabkan DNA target tidak ter amplifikasi. Dengan tersedianya pita DNA yang sesuai dengan panjang target basisnya, maka hasil amplifikasi siap untuk diurutkan.

\section{Analisis Urutan Nukleotida dari Next Generation Sequencing (NGS)}

Sampel DNA Genome kemudian dikirim ke Novogene di Singapura untuk sekuensing NGS. Hasil yang diperoleh berupa pair-end sequencing. Metode ini melakukan sekuensing DNA metagenomik dengan mengurutkan fragmen dan menghasilkan data sekuensing berkualitas tinggi yang dapat disejajarkan. Bacaan yang dibaca kemudian dikelompokkan ke dalam Unit Taksonomi Operasional (OTU), dilakukan anotasi spesies, dan analisis kelimpahan. Kontrol kualitas untuk empat sampel ditunjukkan di bawah ini (Tabel 2).

Tabel 2. Hasil Pembacaan Empat Sampel

\begin{tabular}{cccccccc} 
Sampel & $\begin{array}{c}\text { Raw } \\
\text { Reads }\end{array}$ & $\begin{array}{c}\text { Clean } \\
\text { Reads }\end{array}$ & Jumlah Basa & $\begin{array}{c}\text { Rata }- \text { rata } \\
\text { panjang } \\
\text { nukleotida }\end{array}$ & Q20 & GC\% & Efektivitas \% \\
\hline St 1 & 354.151 & 348.215 & 115.334 .485 & 331 & 98.87 & 39.31 & 97.76 \\
St 2 & 370.845 & 363.975 & 120.545 .946 & 331 & 98.82 & 39.52 & 97.48 \\
St 3 & 379.584 & 372.471 & 123.278 .189 & 331 & 98.87 & 39.13 & 97.46 \\
St 4 & 420.984 & 412.027 & 136.227 .924 & 331 & 98.83 & 39.94 & 97.86 \\
\hline
\end{tabular}

Hasil pengurutan menggunakan NGS Illumina NovaSeq pada Tabel 2 menunjukkan bahwa raw read (hasil pembacaan urutan mentah) lebih tinggi dibandingkan dengan jumlah clean read (hasil pembacaan urutan beranotasi) yang berada pada nilai 354.151 
hingga 420.984 (kelimpahan relatif diatom tingkat ordo yang terbaca bisa dilihat pada gambar 3) Jumlah basa tertinggi terdapat pada stasiun 4, hasil ini sesuai dengan nilai konsentrasinya yang tinggi. Nilai rata-rata setiap panjang nukleotida adalah 331. Kemudian ada nilai Q20 yang merupakan nilai probabilitas kesalahan pembacaan dasar dari 1 - 100. Hasil yang didapat pada keempat sampel tersebut $>98 \%$ yang termasuk dalam kategori baik dalam standar pembacaannya.

Nilai GC yang merupakan nilai persentase basa guanin dan sitosin yang diamati berkisar antara 39,31 - 39,94\%. Nilai GC tersebut bisa dikatakan berada di jangkauan wajar menurut Merino et al [23], namun persentasenya termasuk ke dalam nilai GC yang rendah [24]. Nilai efektifitas adalah nilai yang didapat dari jumlah bacaan mentah dibagi dengan bacaan bersih, hasilnya $>97 \%$. Hasil yang diperoleh menunjukkan bahwa hasil sekuensing berkualitas baik.

Komunitas diatom yang berasosiasi dengan makroalga Padina sp disajikan dalam bentuk diagram di bawah ini untuk mempermudah analisis kelimpahan komunitas diatom antar stasiun. Tinggi rendahnya keragaman komunitas diatom yang terkait dengan makroalga ini dapat dipengaruhi oleh berbagai faktor, antara lain bentuk morfologi permukaan (thallus) dari makroalga [25] dan faktor kualitas lingkungan seperti kecerahan, suhu, unsur hara. , dan salinitas (Mabrouk et al., 2011). Diatom merupakan salah satu mikroorganisme yang paling banyak dijumpai pada biofilm makroalga, hal ini dikarenakan ekosistem vegetatif seperti makroalga menyediakan luas permukaan pada thallus yang kaya bahan organik sebagai habitat yang ideal untuk pertumbuhan diatom epifit [26].

Komunitas diatom pada level order mendapatkan 13 order dan 1 grup unclassified untuk yang tidak diklasifikasikan ke level order (Gambar 3). Hasil yang diperoleh adalah kelimpahan tertinggi pada ordo Bacillariales sebesar $49 \%$ di stasiun $1,41 \%$ di stasiun 2 ,
43\% di stasiun 3 dan $47 \%$ di stasiun 4 . Kelimpahan tinggi lainnya pada keempat sampel tersebut termasuk ordo Naviculales, Fragilariales., dan Thalassiophysales. Untuk ordo yang jumlahnya sedikit, mereka adalah ordo Paraliales, Achnantales, Surirellales, Lithodesmiales, Thalassiosirales, Rhopalodiales, dan Melosirales. Untuk kelompok tidak terklasifikasi tertinggi pada stasiun 4 sebesar $17,33 \%$, dan yang terkecil pada stasiun 1 sebesar $6,82 \%$.

Penelitian tentang keanekaragaman diatom yang terkait dengan makroalga coklat Padina fraseri telah dilakukan oleh [25], hasil penelitiannya menunjukkan bahwa kelimpahan relatif tertinggi diatom berasal dari 3 genera, yaitu Nitzschia, Navicula, dan Cocconeis. Ia juga melaporkan bahwa kelimpahan tertinggi terjadi pada musim semi (September Desember). Hal tersebut tidak jauh berbeda dengan hasil yang diperoleh dimana pengambilan sampel dilakukan pada bulan September. Namun, hal ini tidak dapat digunakan sebagai indikator yang sama karena perbedaan wilayah dan iklim, masih terdapat faktor lain yang mempengaruhi kelimpahan relatif diatom yang terkait dengan makroalga (Phaeophyceae).

Keanekaragaman diatom di perairan Pulau Pramuka dan Pulau Semak Daun yang ditunjukkan dalam bentuk jumlah spesies (kekayaan jenis) dapat diketahui berdasarkan analisis keanekaragaman alfa yang diinterpretasikan oleh Chao1 Index, ACE Index (Abundance-based Coverage Estimator), Indeks Shannon dan Indeks Simpson. Indeks Chao1 dan ACE adalah jumlah kemungkinan kelimpahan spesies dalam komunitas [27]. Berdasarkan Tabel 3, nilai tertinggi pada indeks Chao1 dan ACE berada di Station 4, kemudian disusul Stasiun 3 \& 1, dan nilai terendah ada di Station 2. Hal ini sesuai dengan hasil QC dimana jumlah pembacaan ( Tabel 2) paling banyak dibaca dalam sampel Station. 4, diikuti oleh stasiun 3, stasiun 1, dan stasiun 2 . 


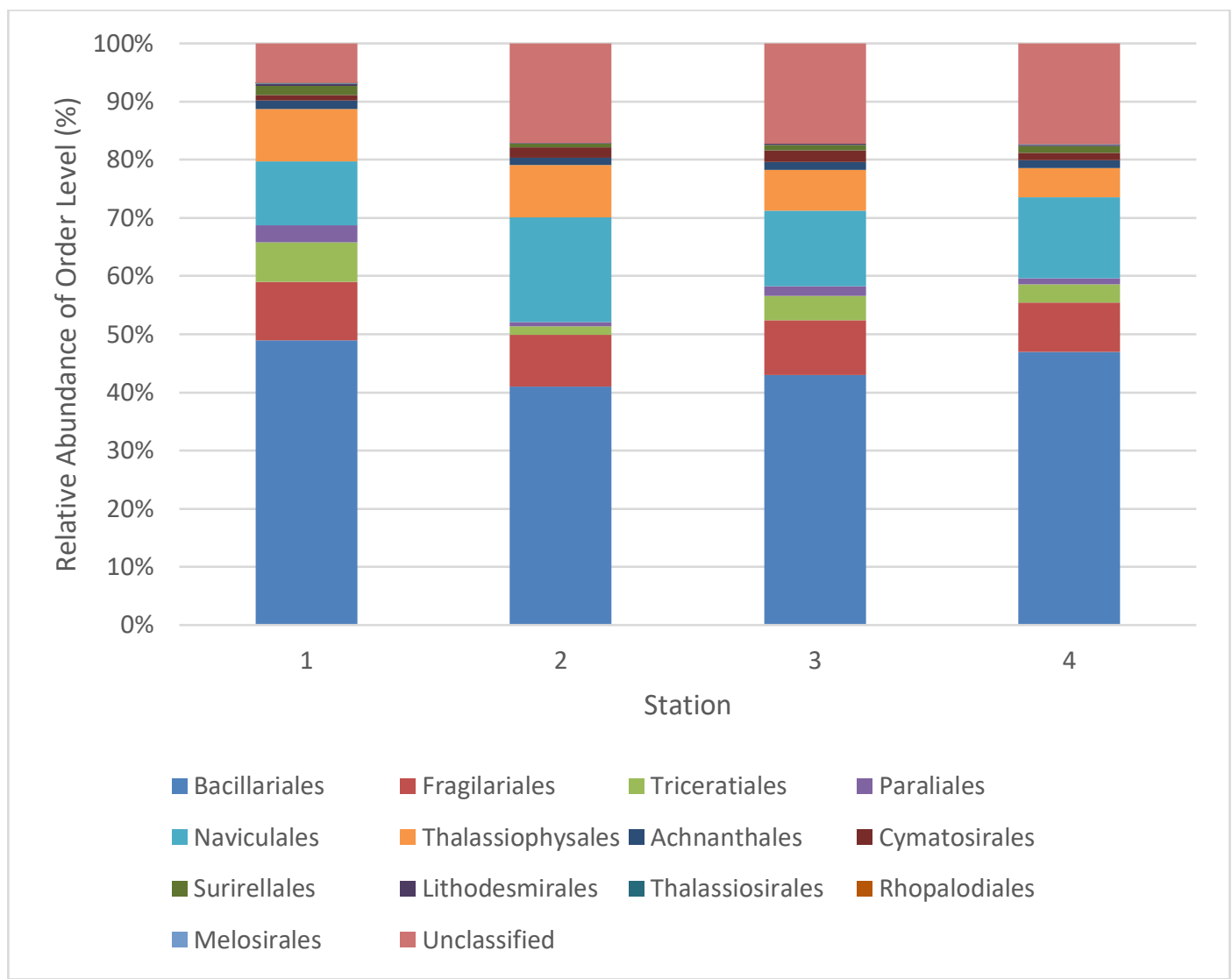

Gambar 3. Kelimpahan Relatif Komunitas Diatom Tingkat Ordo

Sedangkan indeks Shannon $\left(\mathrm{H}^{\prime}\right)$ dan indeks Simpson (D) tidak menunjukkan perbedaan yang signifikan antar stasiun. Menurut Wilhm dan Dorris [28] penentuan kriteria indeks keanekaragaman Shannon $\mathrm{H}^{\prime}<$ 1 maka memiliki keanekaragaman yang rendah, $1<\mathrm{H}^{\prime} \leq 3$ maka memiliki keanekaragaman sedang, $\mathrm{H}^{\prime}>3$ maka memiliki keanekaragaman yang tinggi. Tabel tersebut menunjukkan bahwa keempat sampel tersebut memiliki nilai $\mathrm{H}^{\prime}>3$ yang menunjukkan tingkat keragaman pada keempat stasiun tersebut tinggi. Odum dan Barrett [29] juga menyatakan bahwa penentuan indeks Simpson $0<\mathrm{D} \leq 0,5$ memiliki dominansi rendah, $0,5 \leq \mathrm{D} \leq 0,75$ memiliki dominansi sedang, dan $0,75<\mathrm{D} \leq 1$ memiliki dominansi tinggi. Keempat sampel tersebut memiliki nilai indeks Simpson $0<\mathrm{D}$ $\leq 0,5$ yang menunjukkan indeks dominansi yang rendah. Dari kedua indeks tersebut dapat dilihat dari data kelimpahan relatif spesies pada setiap sampel, dimana kesemuanya tersebar merata dan tidak terdapat kelimpahan yang mencolok satu spesies pada setiap stasiun.
Tabel 3. Indeks Keragaman berdasarkan Keragaman Alpha

\begin{tabular}{ccccc}
\hline Sampel & Chao1 & ACE & H' & D \\
\hline Stasiun 1 & 2541,59 & 3689,79 & 5,21 & 0,013 \\
Stasiun 2 & 2143,73 & 2903,45 & 5,33 & 0,011 \\
Stasiun 3 & 3023,87 & 4706,68 & 5,89 & 0,007 \\
Stasiun 4 & 3227,96 & 4774,28 & 5,93 & 0,008 \\
\hline
\end{tabular}

\section{KESIMPULAN}

Berdasarkan hasil penelitian yang dilakukan dapat disimpulkan bahwa kelimpahan tertinggi pada semua stasiun terdapat di ordo Bacillariales (41 - 49\%), Naviculales (11 - 18\%), dan Fragilariales (8 $10 \%)$.

Indeks Shannon termasuk dalam keragaman tinggi $\left(\mathrm{H}^{\prime}>5\right)$ dan indeks Simpson termasuk dalam dominasi rendah $(0<\mathrm{D} \leq 0,5)$ di semua stasiun. Faktor lingkungan juga mempengaruhi kelimpahan diatom seperti salinitas yang berkorelasi positif dengan kelimpahan ordo Bacillariales. 


\section{UCAPAN TERIMA KASIH}

Penulis mengucapkan terima kasih kepada tim peneliti Riset Fundamental Unpad (RFU) yang telah memberikan bantuan kepada Unpad dalam berbagai hal, baik berupa materi maupun pemikiran.

\section{DAFTAR PUSTAKA}

[1] T. Harder, "Marine Epibiosis: Concepts, Ecological Consequences and Host Defence," in Springer Series on Biofilms, Springer-Verlag Berlin Heidelberg, 2008, pp. 219-231.

[2] F. Goecke, "Associations between microbes and macroalgae: Host, epiphyte and environmental effects," Christian-Albrechts-Universität, 2011.

[3] A. Mantzorou, E. Navakoudis, K. Paschalidis, and F. Ververidis, "Microalgae: a potential tool for remediating aquatic environments from toxic metals," Int. J. Environ. Sci. Technol., vol. 15, no. 8, pp. 18151830, 2018.

[4] P. D. Steinberg and R. De Nys, "Minireview Chemical Mediation of Colonization of Seaweed Surfaces," $J$. Phycol., vol. 629, pp. 621-629, 2002.

[5] T. Staufenberger, V. Thiel, J. Wiese, and J. F. Imhoff, "Phylogenetic analysis of bacteria associated with Laminaria saccharina," FEMS Microbiol. Ecol., vol. 64, no. 1, pp. 6577, 2008.

[6] R. P. Singh, M. K. Shukla, A. Mishra, C. R. K. Reddy, and B. Jha, "Bacterial extracellular polymeric substances and their effect on settlement of zoospore of Ulva fasciata," Colloids Surfaces B Biointerfaces, vol. 103, pp. 223-230, 2013.

[7] T. Lachnit, M. Blümel, J. F. Imhoff, and M. Wahl, "Specific epibacterial communities on macroalgae: Phylogeny matters more than habitat," Aquat. Biol., vol. 5, no. 2, pp. 181-186, 2009.

[8] F. Goecke, A. Labes, J. Wiese, and J. F. Imhoff, "Chemical interactions between Marine macroalgae and bacteria," Mar. Ecol. Prog. Ser., vol.
409, no. June, pp. 267-300, 2010.

[9] C. Burke, T. Thomas, M. Lewis, P. Steinberg, and S. Kjelleberg, "Composition, uniqueness and variability of the epiphytic bacterial community of the green alga Ulva australis," ISME J., vol. 5, no. 4, pp. 590-600, 2011.

[10] C. Burke, P. Steinberg, D. Rusch, S. Kjelleberg, and T. Thomas, "Bacterial community assembly based on functional genes rather than species," Proc. Natl. Acad. Sci. U. S. A., vol. 108, no. 34, pp. 14288-14293, 2011.

[11] A. Ali, S. Soemarno, and M. Purnomo, "Kajian Kualitas Air Dan Status Mutu Air Sungai Metro Di Kecamatan Sukun Kota Malang," Bumi Lestari, vol. 13, no. 2, pp. 265-274, 2013.

[12] F. S. Prasetiya et al., "Haslea nusantara (bacillariophyceae), a new blue diatom from the Java Sea, Indonesia: Morphology, biometry and molecular characterization," Plant Ecol. Evol., vol. 152, no. 2, pp. 188-202, 2019.

[13] J. B. Pouvreau et al., "Antioxidant and free radical scavenging properties of marennine, a blue-green polyphenols pigment from the diatom Haslea ostrearia (Gaillon/Bory) Simonsen responsible for the natural greening of cultured oysters," J. Agric. Food Chem., vol. 56, no. 15, pp. 6278-6286, 2008.

[14] R. Gastineau et al., "Biological activities of purified marennine, the blue pigment responsible for the greening of oysters," J. Agric. Food Chem., vol. 60, no. 14, pp. 3599-3605, 2012.

[15] J. B. Pouvreau et al., "Growth inhibition of several marine diatom species induced by the shading effect and allelopathic activity of marennine, a blue-green polyphenolic pigment of the diatom Haslea ostrearia (Gaillon/Bory) Simonsen," J. Exp. Mar. Bio. Ecol., vol. 352, no. 1, pp. 212-225, 2007.

[16] F. S. Prasetiya et al., "Does allelopathy affect co-culturing Haslea ostrearia with other microalgae relevant to aquaculture?," J. Appl. Phycol., vol. 
28, no. 4, pp. 2241-2254, 2016.

[17] Cambridge Bioscience, "ZymoBIOMICS DNA Kits," 2019. [Online]. Available: https://www.bioscience.co.uk/cpl/zym obiomics-dna-kits. [Accessed: 31-Jan2021].

[18] M. Kelly et al., A DNA based diatom metabarcoding approach for Water Framework Directive classification of rivers, no. March. 2018.

[19] S. I. I. A. Hadi et al., "DNA barcoding green microalgae isolated from neotropical inland waters," PLoS One, vol. 11, no. 2, pp. 1-18, 2016.

[20] P. D. Schloss et al., "Introducing mothur: Open-source, platformindependent, community-supported software for describing and comparing microbial communities," Appl. Environ. Microbiol., vol. 75, no. 23, pp. 7537-7541, 2009.

[21] E. Afgan et al., "The Galaxy platform for accessible, reproducible and collaborative biomedical analyses: 2016 update," Nucleic Acids Res., vol. 44, no. W1, pp. W3-W10, 2016.

[22] B. Batut et al., "Community-Driven Data Analysis Training for Biology," Cell Syst., vol. 6, no. 6, pp. 752-758.e1, 2018.

[23] N. Merino, S. Zhang, M. Tomita, and
H. Suzuki, "Comparative genomics of Bacteria commonly identified in the built environment," BMC Genomics, vol. 20, no. 1, pp. 1-17, 2019.

[24] S. S. Amr and B. Funke, Targeted Hybrid Capture for Inherited Disease Panels. Elsevier Inc., 2015.

[25] S. M. Al Harbi, "Epiphytic Microalgal Dynamics and Species Composition on Brown Seaweeds (Phaeophyceae) on the Northern Coast of Jeddah, Saudi Arabia," J. Oceanogr. Mar. Res., vol. 05, no. 01, pp. 1-9, 2017.

[26] R. Novak, "A Study in Ultra-Ecology: Microorganisms on the Seagrass Posidonia oceanica (L.) DELILE," Mar. Ecol., vol. 5, no. 2, pp. 143-190, 1984.

[27] B. R. Kim et al., "Deciphering diversity indices for a better understanding of microbial communities," J. Microbiol. Biotechnol., vol. 27, no. 12, pp. 20892093, 2017.

[28] J. L. Wilhm and T. C. Dorris, "Biological Parameters for Water Quality Criteria," Bioscience, vol. 18, no. 6, pp. 477-481, 1968.

[29] E. P. Odum and G. W. Barrett, Fundamentals of Ecology, Fifth. Philadelphia: Saunders Company, 1993. 